https://helda.helsinki.fi

\title{
Urban forests near roads do not reduce gaseous air pollutant concentrations but have an impact on particles levels
}

\section{Yli-Pelkonen, Vesa Johannes}

2017

Yli-Pelkonen , V J , Setälä , H M \& Viippola , J V 2017 , ' Urban forests near roads do not reduce gaseous air pollutant concentrations but have an impact on particles levels ' , Landscape and Urban Planning , vol. 158 , pp. 39-47 . https://doi.org/10.1016/j.landurbplan.2016.09.014

http://hdl.handle.net/10138/178483

https://doi.org/10.1016/j.landurbplan.2016.09.014

acceptedVersion

Downloaded from Helda, University of Helsinki institutional repository.

This is an electronic reprint of the original article.

This reprint may differ from the original in pagination and typographic detail.

Please cite the original version. 
2 Urban forests near roads do not reduce gaseous air pollutant concentrations

3 but have an impact on particles levels

4

5 Vesa YLI-PELKONEN ${ }^{1 *}$, Heikki SETÄLÄ ${ }^{2}$, Viljami VIIPPOLA ${ }^{2}$

6

$7{ }^{1}$ University of Helsinki, Department of Environmental Sciences, P.O. Box 65, FI-00014,

8 University of Helsinki, Finland; vesa.yli-pelkonen@helsinki.fi

9

$10{ }^{2}$ University of Helsinki, Department of Environmental Sciences, Niemenkatu 73, FI-15140,

11 Lahti, Finland; heikki.setala@helsinki.fi, viljami.viippola@ helsinki.fi

12

$13 *$ Corresponding author

14 Vesa Yli-Pelkonen

15 Department of Environmental Sciences, P.O. Box 65, FI-00014, University of Helsinki, Finland.

16 Phone: +358 50586 9166; e-mail: vesa.yli-pelkonen@helsinki.fi

17

18

19

20

21

22

23 


\section{Abstract}

25 The ability of urban vegetation to improve air quality for the benefit of urban residents is often

26 considered fact since plants can absorb and capture air pollutants. However, there is little

27 empirical evidence that urban air quality at the local scale is improved by the presence of, e.g.

28 trees, especially in northern climatic regions. We studied the impact of urban forest vegetation

29 on the levels of five types of air pollutants $\left(\mathrm{NO}_{2}\right.$, ground-level $\mathrm{O}_{3}$, anthropogenic and biogenic

30 VOCs, and particulate matter) in near-road environments during summer (June) using passive

31 samplers in Helsinki, Finland. Concentrations of gaseous pollutants did not differ significantly

32 between tree-covered and adjacent open areas, while particle pollutant levels were significantly

33 lower in tree-covered areas than in adjacent open, treeless areas. Vegetation-related variables

34 (canopy closure, tree number and size, and ground vegetation) did not explain differences in air 35 quality. Our results suggest that the role of urban, mostly deciduous, vegetation is negligible in 36 improving local air quality, in terms of the anthropogenic pollutants measured here, in northern

37 climates. However, air particulate pollution, which is likely to be dominated by large-sized

38 particles in our study, can be reduced by urban vegetation.

Highlights:

- Gaseous pollutant concentrations did not differ between tree-covered and open areas

42 - Particle pollutant levels were significantly lower in tree-covered areas

43 - Vegetation-related variables did not explain the difference in particulate levels 


\section{Introduction}

49 Poor air quality due to air pollutants is amongst the most recognized environmental problems in

50 urbanized areas around the world. In Europe, the levels of air pollutants have generally

51 decreased within the past decades, but in many urban areas the levels of particulate matter,

52 nitrogen dioxide $\left(\mathrm{NO}_{2}\right)$, ground-level ozone $\left(\mathrm{O}_{3}\right)$, and anthropogenic volatile organic compounds

53 (AVOC) are still high enough to cause severe risk to human health (EEA, 2014). Most of these

54 air pollutants originate from energy production and road traffic (EEA, 2014).

55

56 Although reducing air pollutant emissions is likely to be the most effective way to improve air

57 quality (EEA, 2014), it is widely believed that vegetation - due to its ability to absorb and capture air pollutants with its large leaf area - can be used to mitigate urban air pollution

59 problems (Beckett, Freer-Smith \& Taylor, 2000a; Nowak, 2006; Nowak, Crane \& Stevens, 60 2006). For example, trees and herbaceous plants capture particulate pollution by dry deposition

61 on their large leaf surfaces (Hofman, Stokkaer, Snauwaert \& Samson, 2013; Räsänen,

62 Holopainen, Joutsensaari, Ndam, Pasanen, Rinnan \& Kivimäenpää, 2013; Weber, Kowarik \& 63 Säumel, 2014).

64

65 Furthermore, trees and other vegetation can absorb gaseous air pollutants, mainly from air to 66 leaf, where gases such as $\mathrm{NO}_{2}$ (Chaparro-Suarez, Meixner \& Kesselmeier, 2011; Rondón \&

67 Granat, 1994; Takahashi, Higaki, Nohno, Kamada, Okamura, Matsui, Kitani \& Morikawa, 68 2005), $\mathrm{O}_{3}$ (Harris \& Manning, 2010; Manes, Incerti, Salvatori, Vitale, Ricotta \& Costanza, 2012;

69 Wang, Zhou, Wang, Gao, Zheng, Tong \& Ouyang, 2012) and anthropogenic volatile organic 
compounds (AVOC) (Doty, James, Moore, Vajzovic, Singleton, Ma, Khan, Xin, Kang, Park, Meilan, Strauss, Wilkerson, Farin \& Strand, 2007; Keymeulen, Schamp \& Van Langenhove, 1995) are absorbed through the stomata into the leaf interior. Consequently, the mitigation of air pollution is often considered an important ecosystem service provided by urban vegetation (e.g. Chaparro \& Terradas, 2009; Jim \& Chen, 2008; Manes et al., 2012; Nowak, Crane, Stevens, Hoehn, Walton \& Bond, 2008).

Forests and other vegetation in rural and urban areas emit biogenic volatile organic compounds (BVOC) while human activities produce AVOCs, which, together with $\mathrm{NO}_{\mathrm{x}}\left(\mathrm{NO}+\mathrm{NO}_{2}\right)$, play a key role in the formation of ozone $\left(\mathrm{O}_{3}\right)$ in the tropospheric air (Calfapietra, Fares, Manes, Morani, Sgrigna \& Loreto, 2013; Loreto \& Schnitzler, 2010). Under VOC-limited conditions, ground-level $\mathrm{O}_{3}$ levels are usually lower in urban (high $\mathrm{NO}_{\mathrm{x}}$ levels) than in rural areas with $\mathrm{NO}_{\mathrm{x}^{-}}$ limited conditions (low $\mathrm{NO}_{\mathrm{x}}$ levels, but higher BVOC levels) (Calfapietra et al., 2013; EEA, 2014). However, in recent years, $\mathrm{O}_{3}$ levels in European and North American cities have increased more than in rural sites, although peak values are decreasing in both environments (Paoletti, De Marco, Beddows, Harrison \& Manning, 2014).

Despite the wealth of studies suggesting that urban vegetation is able to purify air for the benefit of urban inhabitants, contradictory results and comments have emerged recently (Gromke \& Ruck, 2009; Harris \& Manning, 2010; Pataki, Carreiro, Cherrier, Grulke, Jennings, Pincetl, Pouyat, Whitlow \& Zipperer, 2011; Pataki, Alberti, Cadenasso, Felson, McDonnell, Pincetl, Pouyat, Setälä \& Whitlow, 2013; Vos, Maiheu, Vankerkom \& Janssen, 2013). Critique is based on the interpretation of model studies, according to which ambient air quality should uniformly 
93 be improved by the presence of vegetation in the urban environment, where pollutant

94 concentrations are high (e.g. Baumgardner, Varela, Escobedo, Chacalo \& Ochoa, 2012;

95 Hirabayashi, Kroll \& Nowak, 2012; McDonald, Bealey, Fowler, Dragosits, Skiba, Smith,

96 Donovan, Brett, Hewitt \& Nemitz, 2007; Morani, Nowak, Hirabayahsi \& Calfapietra, 2011;

97 Nowak, Hirabayashi, Bodine \& Hoehn, 2013).

98

99 Only a few studies exist in which pollutant levels have been measured locally, e.g. within a

100 forest or park canopy and compared to pollution levels in adjacent open areas (see Brantley,

101 Hagler, Deshmukh \& Baldauf, 2014; Cavanagh, Zawar-Reza \& Wilson, 2009; Freer-Smith,

102 Beckett \& Taylor, 2005; Harris \& Manning, 2010; Setälä, Viippola, Rantalainen, Pennanen \&

103 Yli-Pelkonen, 2013; Streiling \& Matzarakis, 2003; Viippola, Rantalainen, Yli-Pelkonen, Tervo

104 \& Setälä, 2016; Yin, Shen, Zhou, Zou, Che \& Wang, 2011). As such, to enhance our

105 understanding on the uptake, deposition, and re-suspension rates of pollutants by urban

106 vegetation, more on-site, small-scale measuring campaigns are needed (Pataki et al., 2011, 2013;

107 Whitlow, 2009).

108

109 Our main objective is to explore the ability of urban vegetation to purify gaseous and particulate

110 air pollutants of anthropogenic, mostly traffic-derived origin under northern summertime

111 conditions in the near-road environment in Finland. This study builds on the same empirical

112 principles as applied by Setälä et al. (2013), in which air pollutant levels (concentrations of $\mathrm{NO}_{2}$

113 and VOCs and mass deposition of particles) were measured in open and tree-covered areas in

114 late summer and winter using passive samplers in urban near-road environments in two cities

115 (Helsinki and Lahti) in Finland. The present study was conducted during midsummer (mainly 
116 June) when the total leaf-area and gas exchange between leaves and the ambient air is expected

117 to be higher than in Setälä et al. (2013). The sampling protocol of the present study was also

118 slightly different by fine tuning the position of the sampling sites in relation to the prevailing

119 wind direction. Based on previous findings in similar environments (Setälä et al., 2013) we

120 hypothesized that concentrations of gaseous air pollutants should not differ between urban tree-

121 covered and open, treeless areas in near-road environments, while air particulate levels (mass of

122 all deposited particles) should be lower in such tree-covered areas. We also assumed that the

123 removal of pollutants, particularly air particulates, should relate to the volume and structure of

124 vegetation in the tree-covered areas.

125

126 2. Methods

127

128

\subsection{Sampling methods}

129

We measured air pollutant levels using dry deposition passive samplers, placed either under tree canopies in tree-covered areas or in adjacent treeless open areas in near-road environments in the Helsinki Metropolitan Area $\left(60^{\circ} 10^{\prime} 15^{\prime \prime} \mathrm{N}, 2^{\circ} 56^{\prime} 15^{\prime \prime} \mathrm{E}\right)$, southern Finland (Fig. 1). The air

133 pollutants measured were i) nitrogen dioxide $\left(\mathrm{NO}_{2}\right)$, ii) ground-level ozone $\left(\mathrm{O}_{3}\right)$, iii) a selection 134 of typical anthropogenic volatile organic compounds (AVOCs), iv) biogenic volatile organic 135 compounds (BVOCs), which is a selection of the most common monoterpenes in Finnish forests 136 alongside isoprenes (Lindfors \& Laurila, 2000), and v) particulate matter. For $\mathrm{NO}_{2}$ and $\mathrm{O}_{3}$ we 137 used diffusive samplers developed by the Swedish Environmental Research Institute IVL, where 138 the gas is adsorbed to a filter paper inside the collector and the amount of gas is analyzed by 
extracting it from the filter to distilled water, after which the amount of gas is determined with a spectrophotometer (Ferm \& Svanberg, 1998). AVOCs and BVOCs (see Table 3 for the list of compounds) were sampled using diffusive Carbopack B adsorbent tubes and analyzed according to the EN ISO 16017-2 standard, where the concentrations of the studied compounds, counted from individual adsorbent tubes, are determined by comparing them to compound-specific standard substances. VOC results are presented as total AVOCs (= T-AVOCs, including all the sampled AVOC compounds) and as total BVOCs (= T-BVOCs, including all the sampled BVOC compounds). Particle pollution levels were measured using passive collectors developed by IVL (Ferm, Watt, O’Hanlon, De Santis \& Varotsos, 2006). $\mathrm{NO}_{2}$ samplers and their analyses were provided by Metropolilab, Helsinki, Finland, $\mathrm{O}_{3}$ and particle samplers and their analyses by IVL, and VOC samplers and their analyses by Ramboll Analytics, Lahti, Finland.

The sampling of $\mathrm{NO}_{2}, \mathrm{O}_{3}$ and VOCs is based on molecular diffusion. The method has some limitations, but has been successfully used in numerous studies, with results strongly in line with continuous air monitoring (Ayers, Keywood, Gillett, Manins, Malfroy \& Bardsley, 1998; HSY, 2014; Krupa \& Legge, 2000). The passive particle sampling method is based on the deposition of particles by impaction and diffusion on a vertically-mounted cylindrical Teflon surrogate surface. The method does not provide information on the specific particle size fractions, but provides the mass of deposited particles on the sampler surface. Mass is calculated by weighing the surrogate surface before and after exposure. The surrogate surfaces are equilibrated for $24 \mathrm{~h}$ before weighing in a weighing room at $20^{\circ} \mathrm{C}$ and $50 \%$ relative humidity (Ferm et al., 2006). Ferm et al. (2006) noted that particle deposition on Teflon correlated well with $\mathrm{PM}_{10}$ concentrations when samplers were not situated in the immediate vicinity of roads. 
165 Ten sampling sites [different from those in Setälä et al. (2013)] in the Helsinki Metropolitan 166 Area (eight in the city of Helsinki, and one each in the neighboring cities of Espoo and Vantaa, 167 Fig. 1b) were established on the northern side of roads oriented in an east-west direction with 168 moderate to heavy traffic flows (Table 1). This ensured that air pollutant collectors resided 169 downwind from traffic-derived air pollutants. There were no major intersections or roads 170 oriented in a south-north direction, or other roads oriented in a west-east direction to the north of 171 the measuring sites that could potentially have biasing effects. Each of the 10 sites consisted of a 172 pair of sampling units placed on the northern side of the road: one unit in an open area and 173 another in a tree-covered area. The sampling sites were approximately level with the road 174 surface. The open areas were meadows, grasslands or other treeless areas. The soil surface at 175 these open areas was either completely pervious or partly impervious with asphalt walking and 176 cycling paths. The tree-covered areas were mature urban forests of mainly broadleaved trees and 177 a rich understorey layer. Although all sites resided in the urban environment, no buildings or 178 other urban infrastructure existed in close proximity to the sites (see e.g., Fig. 1c).

The samplers were mounted under rain shields fixed to $40 \mathrm{~cm}$-long aluminium L-shaped sampler

181 holders (together forming a sampling unit), which were attached to lamp posts or wooden poles

182 in the open areas. In the tree-covered areas the sampler holders were attached to tree trunks

183 directly under the canopy. The shields and sampler holders were manufactured by IVL. The 184 sampling units for $\mathrm{NO}_{2}$, VOCs and particles were mounted 2.0-3.5 m above ground depending 
185 on a suitable mounting structure. $\mathrm{O}_{3}$ sampling units were mounted $3.2 \mathrm{~m}$ above ground to

186 prevent them from being too close to the ground where $\mathrm{O}_{3}$ gets depleted (Mills, Pleijel, Büker,

187 Braun, Emberson, Harmens, Hayes, Simpson, Grünhage, Karlsson, Danielsson, Bermejo \&

188 Gonzalez Fernandez, 2010). Within each site, the sampling units (open and tree-covered) were

189 always placed at the same distance from the side of the road (a line marking the outer boundary

190 of the road). At different sites, depending on the availability of suitable mounting structures, the

191 sampling unit pairs were situated at slightly different distances from the road side; ranging

192 between 18 and $30 \mathrm{~m}($ mean $=25.6 \mathrm{~m})$. The forest edge in tree-covered areas was, on average,

$1936.2 \mathrm{~m}(0-14 \mathrm{~m})$ from the road side. The area between the road and the forest edge was open

194 with short grass or meadow vegetation. Measurements were carried out during midsummer when

195 plant leaves were fully developed: $\mathrm{NO}_{2}$, VOCs and particle levels were measured from 29 May

196 to 26 June, 2013 (28 days) and $\mathrm{O}_{3}$ was measured from 2 June to 7 July, 2014 (35 days).

197

198 A set of environmental variables was quantified at the sites (Table 1): Canopy closure at the tree-

199 covered areas was estimated using two upwards facing photographs taken $1 \mathrm{~m}$ above ground.

200 One photograph was taken underneath the sampling unit and the second one $5 \mathrm{~m}$ towards the

201 road from the sampling unit. The two photographs represented canopy closure well enough due

202 to the rather homogenous tree/canopy composition within each forested site. The proportion of

203 non-visible sky, a proxy for canopy closure, was calculated using Adobe Photoshop image

204 processing software. The number and size of trees [including trees with a diameter at breast

205 height, $\mathrm{DBH}>2.54 \mathrm{~cm}$ (= 1 inch)], and whether the trees were deciduous or coniferous, were

206 determined from a sector covering $90^{\circ}$ from the sampling unit perpendicular towards the road

207 that delineated the area. The number of trees was converted to represent number per unit area 
$208\left(100 \mathrm{~m}^{2}\right.$ in this case). The extent of ground vegetation (shrubs, bushes, meadow vegetation) was

209 estimated visually at both tree-covered and open areas and classified into dense, intermediate and 210 meager (Table 1).

212 The degree of canopy closure was $84.7 \% \pm 8.0$ (mean \pm SD) in the tree-covered sampling sites.

213 The total number of trees recorded was $73.7 \pm 45.5$, with large trees $(\mathrm{DBH}>32 \mathrm{~cm})$ comprising $2144.4 \%( \pm 5.1)$ of all the trees. The sampling sites were dominated by deciduous trees $(96 \% \pm 7)$, 215 including forest tree species (Betula spp. and Sorbus aucuparia being dominant with scattered 216 Populus spp. and Prunus padus) typical to Southern Finland. Traffic flow data (monthly average, 217 Table 1) were obtained from the City of Helsinki (2012) and the Finnish Transport Agency 218 (2010). Mean annual anthropogenic pollution concentrations, measured at several sampling 219 locations in Helsinki in 2013, were $14-49 \mu \mathrm{g} \mathrm{m}^{-3}$ for $\mathrm{NO}_{2}, 39-52 \mu \mathrm{g} \mathrm{m}^{-3}$ for $\mathrm{O}_{3}, 2-6 \mu \mathrm{g} \mathrm{m}^{-3}$ for 220 AVOCs (benzene, toluene and xylenes combined) and $11-25 \mu \mathrm{g} \mathrm{m}^{-3}$ for $\mathrm{PM}_{10}$ (Air quality in 221 Finland, 2015). Mean annual $\mathrm{NO}_{2}, \mathrm{O}_{3}$ and $\mathrm{PM}_{10}$ concentrations at municipal monitoring stations 222 do not usually exceed annual human health limit values of $40 \mu \mathrm{g} \mathrm{m}^{-3}, 120 \mu \mathrm{g} \mathrm{m}^{-3}$ and $40 \mu \mathrm{g} \mathrm{m}^{-3}$, 223 respectively, with the exception of $\mathrm{NO}_{2}$ in a few highly trafficked locations. Regarding AVOCs, 224 an annual threshold value is available only for benzene $\left(5 \mu \mathrm{g} \mathrm{m}^{-3}\right)$. For BVOCs no threshold 225 values are available. A wind rose showing the prevailing wind direction and speed during the 226 measuring periods is shown in Fig. 2. The monthly average temperature in Helsinki in June 2013 227 was $18.1^{\circ} \mathrm{C}$ and in June $201413.6^{\circ} \mathrm{C}$, representing typical temperatures in June in the Helsinki 228 area. 
232 We analyzed the air pollution data using paired samples $t$-test to determine if there is a difference

233 in pollution levels between the tree-covered and open study areas. We considered $p$-values $<$

2340.05 to indicate statistically significant differences between treatments. Data were $\log _{10}$

235 transformed to stabilize the variance of individual properties where necessary. Linear regression

236 was applied to detect possible correlations between measured environmental variables and

237 pollution level differences between the tree-covered and open areas. In open areas, the influence

238 of ground vegetation on air pollution was tested using the pollution levels of open areas. T-

239 BVOCs were not tested because BVOCs are emitted mainly by trees and not by shrubs and other

240 typical grassland vegetation. The impact of traffic flow on pollution levels was tested using the

241 actual pollutant levels measured at each sampling point, including both open and tree-covered

242 areas. T-BVOCs were not tested because BVOCs are not traffic-emitted substances. Statistical

243 analyses were performed using SPSS Statistics, version 21.

\section{Results}

247 Results for each air pollutant are presented both as means ( \pm SD) of all sites (tree-covered vs.

248 open area comparisons), and for each site separately along the traffic flow gradient (number of

249 motor vehicles day $^{-1}$ ) to explore a potential correlation between pollutant levels and traffic flow

250 (Fig. 3). As for total BVOCs (T-BVOCs), values are presented in relation to \% canopy closure to 251 depict the association between increasing canopy closure and T-BVOC levels (Fig. 3).

252 Concentrations of the gaseous pollutants did not differ significantly between tree-covered and 253 open areas $\left(\mathrm{NO}_{2}, 2.6 \%\right.$ higher in tree-covered areas, $p=0.407 ; \mathrm{O}_{3}, 3.8 \%$ lower in tree-covered 
254 areas, $p=0.177$; total AVOC (T-AVOC), 2.7\% lower in tree-covered areas, $p=0.718$; T-BVOC,

$2559.5 \%$ higher in tree-covered areas, $p=0.432)($ Fig. 3a-d). Thus, tree-cover had no effect on the

256 concentrations of gaseous pollutants, while traffic flow explained most of the variation in $\mathrm{NO}_{2}$

257 concentrations and some of the variation in $\mathrm{O}_{3}$ concentrations between sites (Table 2). For T-

258 AVOCs and particle levels, no such correlation was evident, neither in tree-covered nor in open

259 areas (Table 2). A detailed listing of the constituent AVOCs and BVOCs and their proportions

260 are shown in Table 3. The proportions of AVOC and BVOC constituents were insensitive to the

261 presence of trees (results not shown).

262

263 In contrast to gaseous pollutants, particle pollution levels differed statistically significantly

264 between the tree-covered and open study areas: particle levels were, on average, $23 \%(p=0.023)$

265 lower in tree-covered areas than in open areas (Fig. 3e). None of the measured vegetation

266 properties correlated statistically significantly with the difference in particle levels between the

267 tree-covered and open areas (Table 2). $\mathrm{As} \mathrm{NO}_{2}, \mathrm{O}_{3}$, T-AVOC and T-BVOC concentrations did

268 not differ statistically significantly between tree-covered and open areas, the relationships

269 between their differences and vegetation properties could not be tested.

270

271 None of the vegetation properties measured in the tree-covered areas correlated statistically

272 significantly with T-BVOC levels (results not shown), although there appears to be a trend in T-

273 BVOC levels for total number of trees $(R=0.616, p=0.078)$ and \% canopy closure $(R=0.546$, $274 p=0.129)$.

275

276 4. Discussion 
278 Results from our study, conducted under northern summertime conditions (June), suggest that

279 forest vegetation in near-road urban environments does not improve local air quality in terms of 280 gaseous $\left(\mathrm{NO}_{2}, \mathrm{O}_{3}, \mathrm{AVOCs}\right)$ air pollutants, thus corroborating earlier findings in late summer 281 (August-September) in two Finnish cities (Setälä et al., 2013). In a similar study in Sweden, but 282 only from one measurement site, Grundström and Pleijel (2014) found slightly (7\%) reduced $283 \mathrm{NO}_{2}$ concentrations in the forest canopy. However, besides the canopy effect, this reduction may 284 have resulted from the $4 \mathrm{~m}$ difference in distance between their open and canopy sampling points 285 from a heavy traffic road (the latter being further away from the road) (see e.g. HSY, 2014). In 286 the same study, the authors did not detect reduced $\mathrm{O}_{3}$ concentrations in the canopy (Grundström 287 \& Pleijel, 2014), which is in line with our results. Fantozzi, Monaci, Blanusa \& Bargagli (2015) 288 found lower $\mathrm{NO}_{2}$ concentrations under the canopies of Mediterranean trees (evergreen Quercus 289 ilex L.) growing 1-10 m from a road compared to a nearby open-field transect. However, reduced $290 \mathrm{O}_{3}$ concentrations in the canopy were observed only during post-summer rainfalls (Fantozzi et al. 291 2015), indicating that the impact of vegetation on gaseous pollution concentrations may also 292 depend on the type of local vegetation and climatic conditions. On the other hand, Harris and 293 Manning (2010) found, also using passive samplers, higher $\mathrm{NO}_{2}$ and lower $\mathrm{O}_{3}$ levels within 294 urban tree canopies than outside them. They suggested that this results from $\mathrm{NO}_{\mathrm{x}} / \mathrm{O}_{3}$ chemistry 295 related to gas interactions between soil and the air, as described by Fowler (2002). Although the 296 three gases in our study were sampled at the same locations, $\mathrm{O}_{3}$ was collected a year later than $297 \mathrm{NO}_{2}$ and VOC preventing us from comparing $\mathrm{NO}_{2}$ and VOC levels directly with those of $\mathrm{O}_{3}$. 298 Furthermore, using data collected during one month only to unravel complex interactions 
299 between $\mathrm{NO}_{2}, \mathrm{O}_{3}$ and VOCs is challenging due to the rapid and complex dynamics of these

300 compounds in the air.

301

302 Our results, however, do support earlier studies showing that trees can mitigate problems associated with particulate air pollution (e.g. Beckett et al., 2000a,b; Cavanagh et al., 2009;

Tallis, Taylor, Sinnett \& Freer-Smith, 2011), particularly in the near-road environment (Baldauf,

Thoma, Khlystov, Isakov, Bowker, Long \& Snow, 2008; Islam, Rahman, Bahar, Habib, Ando \&

Hattori, 2012; Maher, Ahmed, Davison, Karloukovski \& Clarke, 2013; Setälä et al., 2013;

307 Steffens, Wang \& Zhang, 2012), although the tree effect can depend on environmental conditions such as wind direction in relation to pollution source, as well as particle size (Brantley et al., 2014; Hagler, Lin, Khlystov, Baldauf, Isakov, Faircloth \& Jackson, 2012; Tong, Whitlow, MacRae, Landers \& Harada, 2015). Although the method used in our study does not allow for the measurement of size fractions of the collected particles, it is likely that coarse particles, most likely road dust, were emphasized in the mass deposition (Ferm et al., 2006); the Teflon sampling surfaces were visibly dirtier close to the road than further away. However, regarding 314 smaller particles, the situation can be different: Tong et al. (2015) investigated the dispersion of particulates near roads using aerosol spectrometers in brief monitoring campaigns and found that

$316 \mathrm{PM}_{2.5}$ concentrations were higher along a transect with trees downwind from the road and 317 declined less sharply than along open transects without trees. Also, as noted by Setälä et al. 318 (2013), particle levels, measured with passive samplers, were notably and significantly lower in 319 tree-covered areas compared to open areas, but often inconsistent with particle data gathered using "active" collecting devices, which can specify particle size fractions and produce results

321 both in mass and number. Considering the particle deposition results and the measuring 
322 methodology in this study, it should be noted that particles that can enter throughout the human

323 respiratory system are smaller than $2.5 \mu \mathrm{m}$ in diameter, and these are easily outweighed by larger

324 particles.

325

326 Sampling in the current study was done in June, i.e. during midsummer in Finland when total

327 leaf area, as well as gas exchange between leaves and ambient air, is high (Rautiainen,

328 Heiskanen \& Korhonen, 2012). However, when comparing our results to Setälä et al. (2013), in

329 which sampling took place in late summer (from early August to early September) when leaf

330 activity is ceasing, it is interesting to note that road-side vegetation did not reduce $\mathrm{NO}_{2}$ and

331 AVOC concentrations neither during mid- nor late summer seasons. In order to explore the

332 canopy effect for the entire growth period, the duration of measuring campaigns during the same

333 year should extend over the entire leaf period.

335 Estimates on the ability of trees to absorb anthropogenic VOCs are based on a few laboratory

336 incubation studies (Cornejo, Munoz, Ma \& Stewart, 1999; Keymeulen et al., 1995; Yang,

337 Pennisi, Son \& Kays, 2009). To our knowledge, the fate of AVOCs in relation to urban

338 vegetation has only been investigated in one study in Las Vegas, U.S. (Hiatt, 1998), where

339 samples of air and leaves of several tree species were analyzed. Hiatt (1998) showed that several

340 local tree species can absorb AVOCs according to existing models. However, our results indicate

341 that the potential of trees to create areas of lower AVOC concentrations at the local scale in

342 northern climates is meager, at least in urbanized sites where deciduous trees constitute most of

343 the vegetation, corroborating Setälä et al. (2013). 
345 Concentrations of BVOCs appeared to be relatively low at most of the study sites (often barely

346 above the detection limit), and were not significantly different between the open and tree-

347 covered areas. Although conifers in Nordic regions are efficient emitters of monoterpenes, some

348 deciduous tree species, such as Betula pendula, B. pubescens, Populus tremula and Salix sp., are

349 also known to emit monoterpenes (Hakola, Rinne \& Laurila, 1999; Lindfors \& Laurila, 2000).

350 Deciduous trees made up most of the canopy cover at our study sites, but BVOC concentrations

351 were equally low in most of the open and tree-covered sites.

353 That concentrations of gaseous pollutants appeared to be unresponsive to forest vegetation, while

354 particle pollution levels were clearly reduced by tree-cover, can be due to the inefficiency of

355 northern vegetation to absorb and process gaseous pollutants, such as $\mathrm{NO}_{2}, \mathrm{O}_{3}$ and $\mathrm{AVOCs}$. The

356 amount of pollutants absorbed by stomatal intake seems to be irrelevant in the context of ambient

357 concentrations. However, even if the vegetation could absorb these pollutants efficiently, it is

358 possible that reduced air flow within tree-covered sites (Belcher, Harman \& Finnigan, 2012;

359 Gromke \& Ruck, 2009; Wuyts, Verheyen, De Schrijver, Cornelis \& Gabriels, 2008) can increase

360 pollutant levels within the canopy and thus have negative impacts on local air quality (see Setälä

361 et al., 2013; Viippola et al., 2016; Vos et al., 2013), while in open areas the polluted air mass is

362 mixed by wind and diluted more rapidly. Such an indirect effect of vegetation on local air quality

363 is seldom reported in the literature and merits more research.

365 The clear reduction in particle levels at tree-covered sites did not relate to any of the measured

366 vegetation properties. It is possible that the vegetation parameters measured here were not

367 instrumental in creating potential variation in air particulate levels and more parameters would 
368 have been needed to tackle this variation. Nevertheless, the reduction in particle levels is best explained by either effective deposition of large (and heavy) particles on vegetation surfaces or

370 perhaps - more importantly - by reduced ventilation under the canopy. Wind speed is known to

371 be lower under thick canopies compared to open, treeless areas (Belcher et al., 2012; Setälä et

372 al., 2013; Wania, Bruse, Blond \& Weber, 2012), which likely prevents road dust from dispersing

373 further away from the road in tree-covered areas.

374

375 Due to the fact that air pollution patterns can be shaped by wind conditions in urban areas (Choi,

376 He, Barbesant, Kozawa, Mara, Winer \& Paulson, 2012; Kozawa, Winer \& Fruin, 2012;

377 McNabola, Broderick \& Gill, 2009), the placement of sampling devices in relation to prevailing

378 wind patterns deserved attention in our study set-up. As the prevailing wind direction (long-term

379 average) in June in Helsinki is from the south or south-west, all sampling sites were placed

380 downwind from the pollution source. Wind direction, however, varied considerably during the

381 one-month measuring periods in 2013 and 2014 and no clear consistency in wind direction at the

382 study region was evident (Fig. 2). However, south-western and eastern winds dominated, and

383 only a small percentage of winds blew from the north in June 2013. Thus, for most of that

384 campaign period, our sampling units were downwind or at least in a neutral position, but clearly

385 not upwind, in relation to pollution sources. In June 2014, when $\mathrm{O}_{3}$ was measured, winds blew

386 from almost all directions. Moreover, the relatively long sampling period used is bound to

387 diminish the impacts of short-term wind direction changes and local eddies on our results. The

388 concentrations of $\mathrm{NO}_{2}, \mathrm{O}_{3}$ and AVOCs were in line with the available mean annual and monthly

389 (June 2013) concentration data from Helsinki, and always below the limit values for human

390 health (Air quality in Finland, 2015; HSY, 2014). 


\section{Conclusions}

The current study conducted in Helsinki corroborates results from other studies in Nordic urban environments (Setälä et al., 2013; Viippola et al., 2016); the impact of the tree canopy, at least in near-road environments without buildings, is negligible regarding the concentrations of certain 397 gaseous air pollutants. Alternatively, it may be that these gaseous pollutants were absorbed to 398 some extent by the canopy, but not sufficiently so to compensate for increased concentrations 399 due to reduced air-flow in tree-covered areas (see Janhäll, 2015). However, the levels of coarse 400 particulate matter were reduced by the presence of trees. The methodology used does not allow 401 for the extrapolation of this conclusion to fine particles. Our results - obtained from the period 402 when gas exchange between foliage and the atmosphere is most active - thus suggest that forest 403 vegetation does not necessarily reduce air pollutant levels in urban areas. However, further 404 empirical field research on the mechanisms and factors contributing to the various direct and 405 indirect impacts of vegetation on air pollutant levels is needed.

\section{Acknowledgments}

408 We thank Johan Kotze for checking the English and for many helpful comments. This study was

409 funded by the Helsinki Metropolitan Region Urban Research Program and the Helsinki

410 University Centre for Environment (HENVI, ENSURE research programme). 


\section{References}

1. Air quality in Finland (2015). Retrieved January 2, 2015 from - http://www.ilmanlaatu.fi

2. Ayers, G. P., Keywood, M. D., Gillett, R., Manins, P. C., Malfroy, H., Bardsley, T. (1998). Validation of passive diffusion samplers for $\mathrm{SO}_{2}$ and $\mathrm{NO}_{2}$. Atmospheric Environment, 32, 3587-3592.

3. Baldauf, R., Thoma, E., Khlystov, A., Isakov, V., Bowker, G., Long, T., \& Snow, R. (2008). Impact of noise barriers on near-road air quality. Atmospheric Environment, 42, $7502-7507$.

4. Baumgardner, D., Varela, S., Escobedo, F. J., Chacalo, A., \& Ochoa, C. (2012). The role of peri-urban forest on air quality improvement in the Mexico City megalopolis. Environmental Pollution, 163, 174-183.

5. Beckett, K. P., Freer-Smith, P. H., \& Taylor, G. (2000a). The capture of particulate pollution by trees at five contrasting urban sites. Arboricultural Journal, 24, 209-230.

6. Beckett, K. P., Freer-Smith, H. P., \& Taylor, G., (2000b). Particulate pollution capture by urban trees: effect of species and windspeed. Global Change Biology, 6, 995-1003.

7. Belcher, S. E., Harman, I. N., \& Finnigan, J. J. (2012). The wind in the willows: flows in forest canopies in complex terrain. Annual Review of Fluid Mechanics, 44, 479-504.

8. Brantley, H. L., Hagler, G. S. W., Deshmukh, P. J., \& Baldauf, R. W. (2014). Field assessment of the effects of roadside vegetation on near-road black carbon and particulate matter. Science of the Total Environment, 468-469, 120-129.

9. Calfapietra, C., Fares, S., Manes, F., Morani, A., Sgrigna, G., \& Loreto, F. (2013). Role of Biogenic Volatile Compounds (BVOC) emitted by urban trees on ozone concentration in cities: A review. Environmental Pollution, 183, 71-80.

10. Cavanagh, J.-O. E., Zawar-Reza, P., \& Wilson, J. G. (2009). Spatial attenuation of ambient particulate matter air pollution within an urbanised forest patch. Urban Forestry \& Urban Greening, 8, 21-30.

11. Chaparro, L., \& Terradas, J. (2009). Ecological Services of Urban Forest in Barcelona. Centre de Recerca Ecologica in Aplicacions Forestals, Universitat Autonoma de Barcelona, Spain. 
12. Chaparro-Suarez, I. G., Meixner, F. X., \& Kesselmeier, J. (2011). Nitrogen dioxide $\left(\mathrm{NO}_{2}\right)$ uptake by vegetation controlled by atmospheric concentrations and plant stomatal aperture. Atmospheric Environment, 45, 5742-5750.

13. Choi, W., He, M., Barbesant, V., Kozawa, K. H., Mara, S., Winer, A. M., \& Paulson, S. E. (2012). Prevalence of wide area impacts downwind of freeways under pre-sunrise stable atmospheric conditions. Atmospheric Environment, 62, 318-327.

14. City of Helsinki (2012). Traffic volumes on main streets of Helsinki, September 2012. City Planning Department, Transportation and Travel Planning.

15. Cornejo, J. J., Munoz, F. G., Ma, C. Y., \& Stewart, A. J. (1999). Studies on the decontamination of air by plants. Ecotoxicology, 8, 311-320.

16. Doty, S. L., James, C. A., Moore, A. L., Vajzovic, A., Singleton, G. L., Ma, C., Khan, Z., Xin, G., Kang, J. W., Park, J. Y., Meilan, R., Strauss, S. H., Wilkerson, J., Farin, F., \& Strand, S. E. (2007). Enhanced phytoremediation of volatile environmental pollutants with transgenic trees. PNAS, 104, 16816-16821.

17. EEA (2014). Air quality in Europe - 2014 report. European Environment Agency EEA Report No 5/2014. Retrieved January 1, 2015 from http://www.eea.europa.eu/publications/air-quality-in-europe-2014

18. Fantozzi, F., Monaci, F., Blanusa, T., \& Bargagli, R. (2015). Spatio-temporal variations of ozone and nitrogen dioxide concentrations under urban trees and in a nearby open area. Urban Climate, 12, 119-127.

19. Ferm, M., \& Svanberg, P.-A. (1998). Cost-efficient techniques for urban- and background measurements of $\mathrm{SO}_{2}$ and $\mathrm{NO}_{2}$. Atmospheric Environment, 32, 1377-1381.

20. Ferm, M., Watt, J., O’Hanlon, S., De Santis, F., \& Varotsos, C. (2006). Deposition measurement of particulate matter in connection with corrosion studies. Analytical and Bioanalytical Chemistry, 384, 1320-1330.

21. Finnish Transport Agency (2010). Traffic flow map of Uusimaa region 2010. Retrieved 5 September, 2016 from http://www.liikennevirasto.fi/tilastot/tietilastot/liikennemaarakartat1/vanhatliikennemaarakartat 
22. Freer-Smith, P. H., Beckett, K. P., \& Taylor, G. (2005). Deposition velocities to Sorbus aria, Acer campestre, Populus deltoids $\times$ trichocarpa 'Beaupré', Pinus nigra and $\times$ Cupressocyparis leylandii for coarse, fine and ultra-fine particles in the urban environment. Environmental Pollution, 133, 157-167.

23. Fowler, D. (2002). Pollutant deposition and uptake by vegetation. In J. N. B. Bell, \& M. Treshow (Eds.), Air Pollution and Plant Life (pp. 43-67). John Wiley and Sons, Ltd., New York.

24. Gromke, C., \& Ruck, B. (2009). On the impact of trees on dispersion processes of traffic emissions in street canyons. Boundary-Layer Meteorology, 131, 19-34.

25. Grundström, M., \& Pleijel, H. (2014). Limited effect of urban tree vegetation on $\mathrm{NO}_{2}$ and $\mathrm{O}_{3}$ concentrations near a traffic route. Environmental Pollution, 189, 73-76.

26. Hagler, G. S. W., Lin, M. Y., Khlystov, A., Baldauf, R. W., Isakov, V., Faircloth, J., \& Jackson, L. E. (2012). Field investigation of roadside vegetative and structural barrier impact on near-road ultrafine particle concentration under a variety of wind conditions. Science of the Total Environment, 419, 7-15.

27. Hakola, H., Rinne, J., \& Laurila, T. (1999). The VOC emission rates of boreal deciduous trees. In T. Laurila, \& V. Lindfors (Eds.), Biogenic VOC emissions and photochemistry in the boreal regions of Europe (pp. 21-28). Air Pollution Research Report 70, Commission of the European Communities, Luxembourg.

28. Harris, T. B., \& Manning, W. J. (2010). Nitrogen dioxide and ozone levels in urban tree canopies. Environmental Pollution, 158, 2384-2386.

29. Hiatt, M. H. (1998). Bioconcentration factors for volatile organic compounds in vegetation. Analytical Chemistry, 70, 851-856.

30. Hirabayashi, S., Kroll, C. N., \& Nowak, D. J. (2012). Development of a distributed air pollutant dry deposition modeling framework. Environmental Pollution, 171, 9-17.

31. Hofman, J., Stokkaer, I., Snauwaert, L., \& Samson, R. (2013). Spatial distribution assessment of particulate matter in an urban street canyon using biomagnetic leaf monitoring of tree crown deposited particles. Environmental Pollution, 183, 123-132.

32. HSY (Helsinki Region Environmental Services Authority) (2014). Ilmanlaatu pääkaupunkiseudulla vuonna 2013 (Air Quality in the Helsinki Metropolitan Area in 
2013). HSY publications 3/2014. [in Finnish with an abstract in English] Retrieved 5 September, 2016 from https://www.hsy.fi/sites/Esitteet/EsitteetKatalogi/Julkaisusarja/3_2014_Ilmanlaatu_paaka upunkiseudulla_2013.pdf

33. Islam, M. N., Rahman, K.-S., Bahar, M. M., Habib, M. A., Ando, K., \& Hattori, N. (2012). Pollution attenuation by roadside greenbelt in and around urban areas. Urban Forestry \& Urban Greening, 11, 460-464.

34. Janhäll, S. (2015). Review on urban vegetation and particle pollution - Deposition and dispersion. Atmospheric Environment, 105, 130-137.

35. Jim, C. Y., \& Chen, W. Y. (2008). Assessing the ecosystem service of air pollutant removal by urban trees in Guangzhou (China). Journal of Environmental Management, $88,665-676$.

36. Keymeulen, R., Schamp, N., \& Van Langenhove, H. (1995). Uptake of gaseous toluene in plant leaves: a two compartment model. Chemosphere, 31, 3961-3975.

37. Kozawa, H. K., Winer, A. M., \& Fruin, S. A. (2012). Ultrafine particle size distributions near freeways: Effects of differing wind directions on exposure. Atmospheric Environment, 63, 250-260.

38. Krupa, S. V., \& Legge, A. H. (2000). Passive sampling of ambient, gaseous air pollutants: An assessment from an ecological perspective. Environmental Pollution, 107, $31-45$.

39. Lindfors, V., \& Laurila, T. (2000). Biogenic volatile organic compound (VOC) emissions from forests in Finland. Boreal Environment Research, 5, 95-113.

40. Loreto, F., \& Schnitzler, J.-P. (2010). Abiotic stresses and induced BVOCs. Trends in Plant Science, 15, 154-166.

41. Maher, B. A., Ahmed, I. A. M., Davison, B., Karloukovski, V., \& Clarke, R. (2013) Impact of roadside tree lines on indoor concentrations of traffic-derived particulate matter. Environmental Science \& Technology, 47, 13737-13744.

42. Manes, F., Incerti, G., Salvatori, E., Vitale, M., Ricotta, C., \& Costanza, R. (2012). Urban ecosystem services: tree diversity and stability of tropospheric ozone removal. Ecological Applications, 22, 349-360. 
43. McDonald, A. G., Bealey, W. J., Fowler, D., Dragosits, U., Skiba, U., Smith, R. I., Donovan, R. G., Brett, H. E., Hewitt, C. N., \& Nemitz, E. (2007). Quantifying the effect of urban tree planting on concentrations and depositions of $\mathrm{PM}_{10}$ in two UK conurbations. Atmospheric Environment, 41, 8455-8467.

44. McNabola, A., Broderick, B. M., \& Gill, L. W. (2009). A numerical investigation of the impact of low boundary walls on pedestrian exposure to air pollutants in urban street canyons. Science of The Total Environment, 407, 760-769.

45. Mills, G., Pleijel, H., Büker, P., Braun, S., Emberson, L., Harmens, H., Hayes, F., Simpson, D., Grünhage, L., Karlsson, P.-E., Danielsson, H., Bermejo, V., \& Gonzalez Fernandez, I. (Eds.) (2010). Chapter 3 of the LRTAP Convention Manual on Methodologies and Criteria for Modelling and Mapping Critical Loads \& Levels and Air Pollution Effects, Risks and Trends. Retrieved 5 September, 2016 from http://www.rivm.nl/media/documenten/cce/manual/Ch3revisedsummer2010updatedJune 2011.pdf

46. Morani, A., Nowak, D. J., Hirabayahsi, S., \& Calfapietra, C. (2011). How to select the best tree planting locations to enhance air pollution removal in the MillionTreesNYC initiative. Environmental Pollution, 159, 1040-1047.

47. Nowak, D. J. (2006). Institutionalizing urban forestry as a "biotechnology" to improve environmental quality. Urban Forestry \& Urban Greening, 5, 93-100.

48. Nowak, D. J., Crane, D. E., \& Stevens, J. C. (2006). Air pollution removal by urban trees and shrubs in the United States. Urban Forestry \& Urban Greening, 4, 115-123.

49. Nowak, D. J., Crane, D. E., Stevens, J. C., Hoehn, R. E., Walton, J. T., \& Bond, J. (2008). A ground-based method of assessing urban forest structure and ecosystem services. Arboriculture \& Urban Forestry, 34, 347-358.

50. Nowak, D. J., Hirabayashi, S., Bodine, A., \& Hoehn, R. (2013). Modeled PM 2.5 removal by ten U.S. cities and associated health effects. Environmental Pollution, 178, 395-402.

51. Paoletti, E., De Marco, A., Beddows, D. C. S., Harrison, R. M., \& Manning, W.J. (2014). Ozone levels in European and USA cities are increasing more than at rural sites, while peak values are decreasing. Environmental Pollution, 192, 295-299. 
52. Pataki, D. E., Alberti, M., Cadenasso, M. L., Felson, A. J., McDonnell, M. J., Pincetl, S., Pouyat, R. V., Setälä, H., \& Whitlow, T. H. (2013). City trees: Urban greening needs better data. Nature, 502, 624.

53. Pataki, D. E., Carreiro, M. M., Cherrier, J., Grulke, N. E., Jennings, V., Pincetl, S., Pouyat, R. V., Whitlow, T. H., \& Zipperer, W. C. (2011). Coupling biogeochemical cycles in urban environments: ecosystem services, green solutions, and misconceptions. Frontiers in Ecology and the Environment, 9, 27-36.

54. Rautiainen, M., Heiskanen, J., \& Korhonen, L. (2012). Seasonal changes in canopy leaf area index and MODIS vegetation products for a boreal forest site in Central Finland. Boreal Environment Research, 17, 72-84.

55. Rondón, A., \& Granat, L. (1994). Studies on the dry deposition of $\mathrm{NO}_{2}$ to coniferous species at low $\mathrm{NO}_{2}$ concentrations. Tellus, 46B, 339-352.

56. Räsänen, J. V., Holopainen, T., Joutsensaari, J., Ndam, C., Pasanen, P., Rinnan, Å., \& Kivimäenpää, M. (2013). Effects of species-specific leaf characteristics and reduced water availability on fine particle capture efficiency of trees. Environmental Pollution, $183,64-70$.

57. Setälä, H., Viippola, V., Rantalainen, A.-L., Pennanen, A., \& Yli-Pelkonen, V. (2013). Does urban vegetation mitigate air pollution in northern conditions? Environmental Pollution, 183, 104-112.

58. Steffens, J. T., Wang, Y. J., \& Zhang, K. M. (2012). Exploration of effects of a vegetation barrier on particle size distribution in a near-road environment. Atmospheric Environment, 50, 120-128.

59. Streiling, S., \& Matzarakis, A. (2003). Influence of single and small clusters of trees on the bioclimate of a city: A case study. Journal of Arboriculture, 29, 309-316.

60. Takahashi, M., Higaki, A., Nohno, M., Kamada, M., Okamura, Y., Matsui, K., Kitani, S., \& Morikawa, H. (2005). Differential assimilation of nitrogen dioxide by 70 taxa of roadside trees at an urban pollution level. Chemosphere, 61, 633-639.

61. Tallis, M., Taylor, G., Sinnett, D., \& Freer-Smith, P. (2011). Estimating the removal of atmospheric particulate pollution by the urban tree canopy of London, under current and future environments. Landscape and Urban Planning, 103, 129-138. 
62. Tong, Z., Whitlow, T. H., MacRae, P. F., Landers, A. J., \& Harada, Y. (2015). Quantifying the effect of vegetation on near-road air quality using brief campaigns. Environmental Pollution, 201, 141-149.

63. Viippola, V., Rantalainen, A.-L., Yli-Pelkonen, V., Tervo, P., \& Setälä, H. (2016). Gaseous polycyclic aromatic hydrocarbon concentrations are higher in urban forests than adjacent open areas during summer but not in winter - Exploratory study. Environmental Pollution, 208, 233-240.

64. Vos, P. E. J., Maiheu, B., Vankerkom, J., \& Janssen, S. (2013). Improving local air quality in cities: To tree or not to tree? Environmental Pollution, 183, 113-122.

65. Wang, H., Zhou, W., Wang, X., Gao, F., Zheng, H., Tong, L., \& Ouyang, Z. (2012). Ozone uptake by adult urban trees based on sap flow measurement. Environmental Pollution, 162, 275-286.

66. Wania, A., Bruse, M., Blond, N., \& Weber, C. (2012). Analysing the influence of different street vegetation on traffic-induced particle dispersion using microscale simulations. Journal of Environmental Management, 94, 91-101.

67. Weber, F., Kowarik, I., \& Säumel, I. (2014). Herbaceous plant as filters: Immobilization of particulates along urban street corridors. Environmental Pollution, 186, 234-240.

68. Whitlow, T. (2009). Determining the fate of $P M_{2.5}$ particles following capture by leaves. Ithaca, NY: Cornell University. Final Technical Report. Retrieved 5 September, 2016 from - http://www.urbanforestrysouth.org/research/nucfac/determining-the-fate-of-pm-25-particles-following-capture-by-leaves-05-dg-11233225-228

69. Wuyts, K., Verheyen, K., De Schrijver, A., Cornelis, W. M., \& Gabriels, D. (2008). The impact of forest edge structure on longitudinal patterns of deposition, wind speed, and turbulence. Atmospheric Environment, 42, 8651-8660.

70. Yang, D. S., Pennisi, S. V., Son, K.-C., \& Kays, S. J. (2009). Screening indoor plants for volatile organic pollutant removal efficiency. HortScience, 44, 1377-1381.

71. Yin, S., Shen, Z., Zhou, P., Zou, X., Che, S., \& Wang, W. (2011). Quantifying air pollution attenuation within urban parks: An experimental approach in Shanghai, China. Environmental Pollution, 159, 2155-2163. 


\section{LIST OF TABLES}

Table 1. Environmental variables measured at the 10 study sites in the Helsinki Metropolitan Area arranged by ascending traffic flow (number of motor vehicles day ${ }^{-1}$, monthly average for June). Values referring to canopy closure, trees and ground vegetation were estimated from a sector covering 90 degrees from the sampling unit towards the road that delineated the area. Trees with a diameter at breast height $(\mathrm{DBH})$ of $<2.54 \mathrm{~cm}(=1 \mathrm{inch})$ are not included.

\begin{tabular}{|c|c|c|c|c|c|c|}
\hline Site & $\begin{array}{l}\text { Canopy } \\
\text { closure }(\%)\end{array}$ & $\begin{array}{l}\text { Total nr. of } \\
\text { trees } 100 \mathrm{~m}^{-2}\end{array}$ & $\begin{array}{l}\text { Nr. of trees with DBH } \\
>32 \mathrm{~cm} 100 \mathrm{~m}^{-2}\end{array}$ & $\begin{array}{l}\text { Tree-covered area } \\
\text { - ground vegetation }\end{array}$ & $\begin{array}{l}\text { Open area - } \\
\text { ground vegetation }\end{array}$ & $\begin{array}{l}\text { Traffic } \\
\text { flow }\end{array}$ \\
\hline 1 & 71 & 13.0 & 0 & dense & dense & 8000 \\
\hline 2 & 75 & 7.0 & 0.3 & intermediate & dense & 14100 \\
\hline 3 & 95 & 19.4 & 1.2 & meager & intermediate & 14700 \\
\hline 4 & 82 & 17.6 & 0.6 & intermediate & intermediate & 14800 \\
\hline 5 & 89 & 7.4 & 0.4 & intermediate & dense & 52600 \\
\hline 6 & 94 & 3.3 & 0.6 & intermediate & dense & 58500 \\
\hline 7 & 88 & 13.8 & 0 & meager & intermediate & 64100 \\
\hline 8 & 78 & 7.8 & 0 & intermediate & meager & 65000 \\
\hline 9 & 89 & 5.8 & 0.5 & dense & dense & 91600 \\
\hline 10 & 87 & 21.4 & 0.2 & intermediate & intermediate & 102400 \\
\hline
\end{tabular}


Table 2. Relationship between vegetation properties and the statistically significant air quality difference of particle levels*. The difference is calculated by subtracting particle levels detected in the tree-covered areas from that in the open areas. Linear regression was used to detect relationships and their statistical significances. The influence of ground vegetation of the open areas was tested using the pollution levels of the open areas (except for T-BVOCs that are mainly emitted by trees). The impact of traffic flow on pollution levels (except for T-BVOCs that are not traffic-emitted) was tested using the actual pollutant levels measured at each sampling point, including both open and tree-covered areas. Statistically significant $R$ values are marked in bold.

* = Regarding $\mathrm{NO}_{2}, \mathrm{O}_{3}$, T-AVOCs and T-BVOCs, the differences between tree-covered and open areas were not statistically significant, and thus the relationships between their differences and vegetation properties were not tested (reason for blank lines). ${ }^{\mathrm{a}} n=10$.

${ }^{\mathrm{b}}$ For traffic flow, $n=20$, except for T-AVOC $(n=19)$.

\begin{tabular}{|c|c|c|c|c|c|c|c|}
\hline & & $\begin{array}{l}\text { Canopy } \\
\text { closure }^{\text {a }}\end{array}$ & $\begin{array}{l}\text { Total } \mathrm{nr} \text { of trees } \\
100 \mathrm{~m}^{-2} \mathrm{a}\end{array}$ & $\begin{array}{l}\text { Nr of trees with DBH } \\
>32{\mathrm{~cm} 100 \mathrm{~m}^{-2} \mathrm{a}}^{2}\end{array}$ & $\begin{array}{l}\text { Tree-covered } \\
\text { area's ground } \\
\text { vegetation }^{\text {a }}\end{array}$ & $\begin{array}{l}\text { Open area's } \\
\text { ground } \\
\text { vegetation }^{\text {a }}\end{array}$ & Traffic flow ${ }^{\mathrm{b}}$ \\
\hline \multirow[t]{2}{*}{ P-dep. } & $R$ & 0.023 & 0.484 & 0.090 & 0.036 & 0.138 & 0.024 \\
\hline & $p$ & 0.950 & 0.157 & 0.804 & 0.921 & 0.704 & 0.920 \\
\hline \multirow[t]{2}{*}{$\mathrm{NO}_{2}$} & $R$ & - & - & - & - & 0.130 & 0.787 \\
\hline & $p$ & - & - & - & - & 0.720 & $<0.001$ \\
\hline \multirow[t]{2}{*}{$\mathrm{O}_{3}$} & $R$ & - & - & - & - & 0.074 & 0.545 \\
\hline & $p$ & - & - & - & - & 0.839 & 0.013 \\
\hline \multirow[t]{2}{*}{ T-AVOC } & $R$ & - & - & - & - & 0.169 & 0.207 \\
\hline & $p$ & - & - & - & - & 0.642 & 0.395 \\
\hline
\end{tabular}


Table 3. List of anthropogenic (AVOC) and biogenic (BVOC) volatile organic compounds and their relative proportions in the samples. Values shown are mean proportions of all the samples collected at the tree-covered and open areas.

\begin{tabular}{lc}
\hline AVOC & proportion \\
\hline Toluene & $34 \%$ \\
Benzene & $12 \%$ \\
Ethylbenzene & $7.7 \%$ \\
o-xylene & $9.7 \%$ \\
$m / p$-xylene & $22 \%$ \\
Styrene & $2.3 \%$ \\
Ethyl tert-butyl ether & $0.9 \%$ \\
Propylbenzene & $1.6 \%$ \\
2-Ethyltoluene & $2.9 \%$ \\
3-Ethyltoluene & $5.2 \%$ \\
4-Ethyltoluene & $1.8 \%$ \\
\hline BVOC & \\
\hline a-pinene & $47 \%$ \\
b-pinene & $13 \%$ \\
d-carene & $13 \%$ \\
limonene & $26 \%$ \\
\hline
\end{tabular}




\section{LIST OF FIGURES}

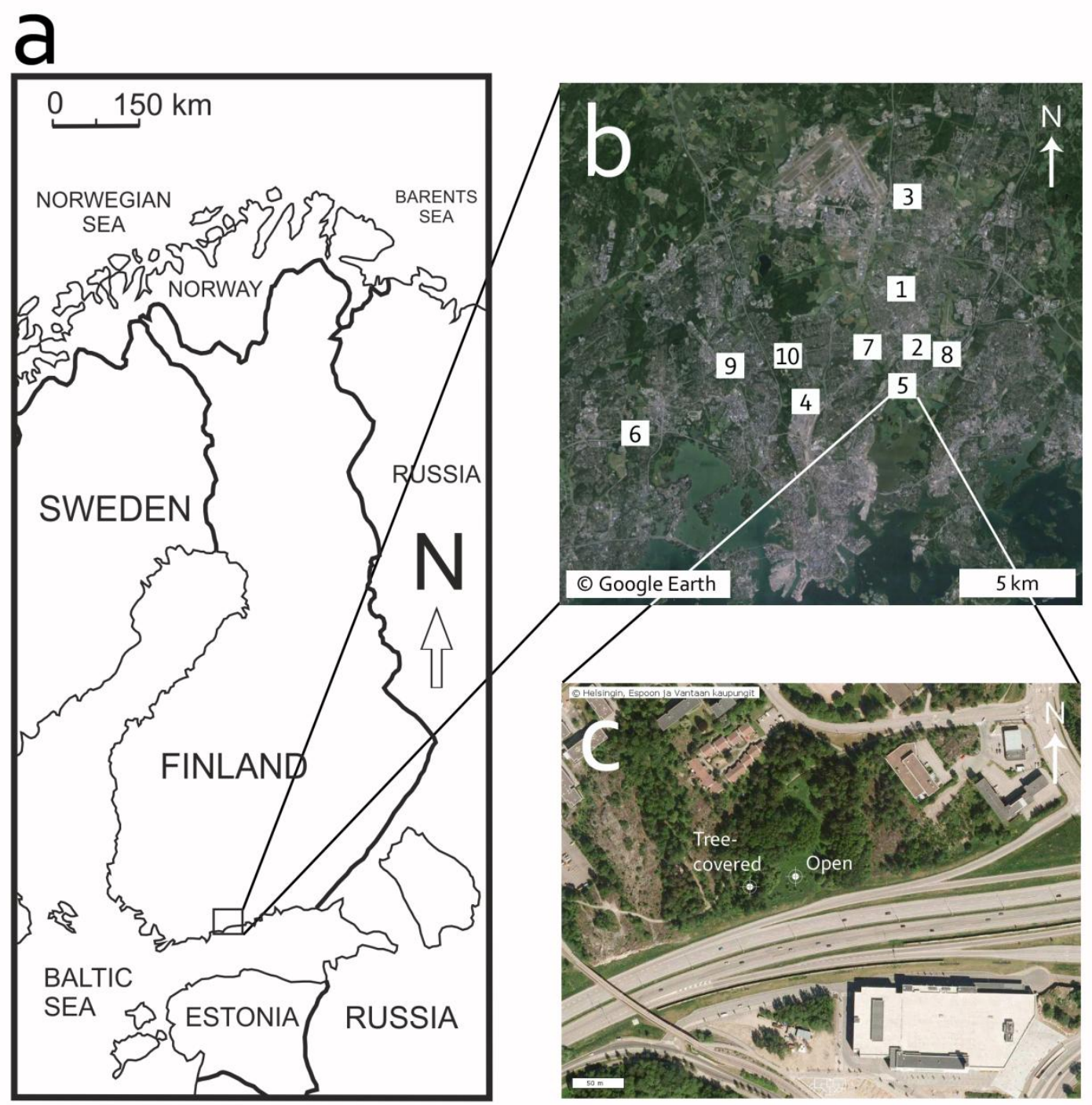

Fig. 1. (a) A map of Finland with (b) an aerial image of the Helsinki Metropolitan Area displaying locations of the ten sampling sites $(1-10)$, and (c) an aerial image of one of the sampling sites (site 5) as an example. At each of the 10 sites, air quality was measured in one tree-covered and one open area. At site 5, sampling units were placed ca. $30 \mathrm{~m}$ from the road edge. 

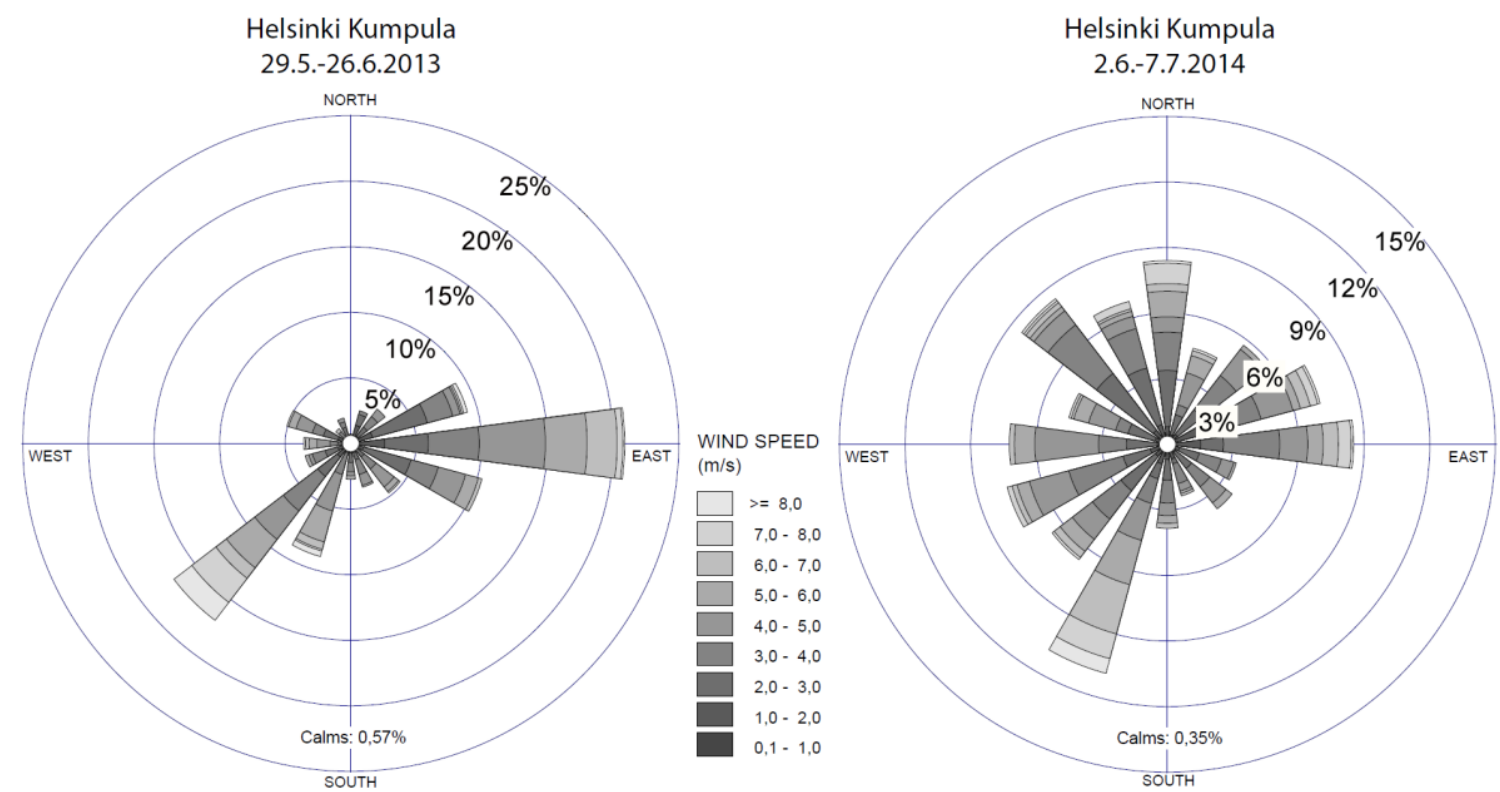

Fig. 2. Wind direction and speed during 29 May - 26 June, 2013 and 2 June - 7 July, 2014 in Helsinki (Kumpula measuring station). Data were provided by the Finnish Meteorological Institute (FMI). 

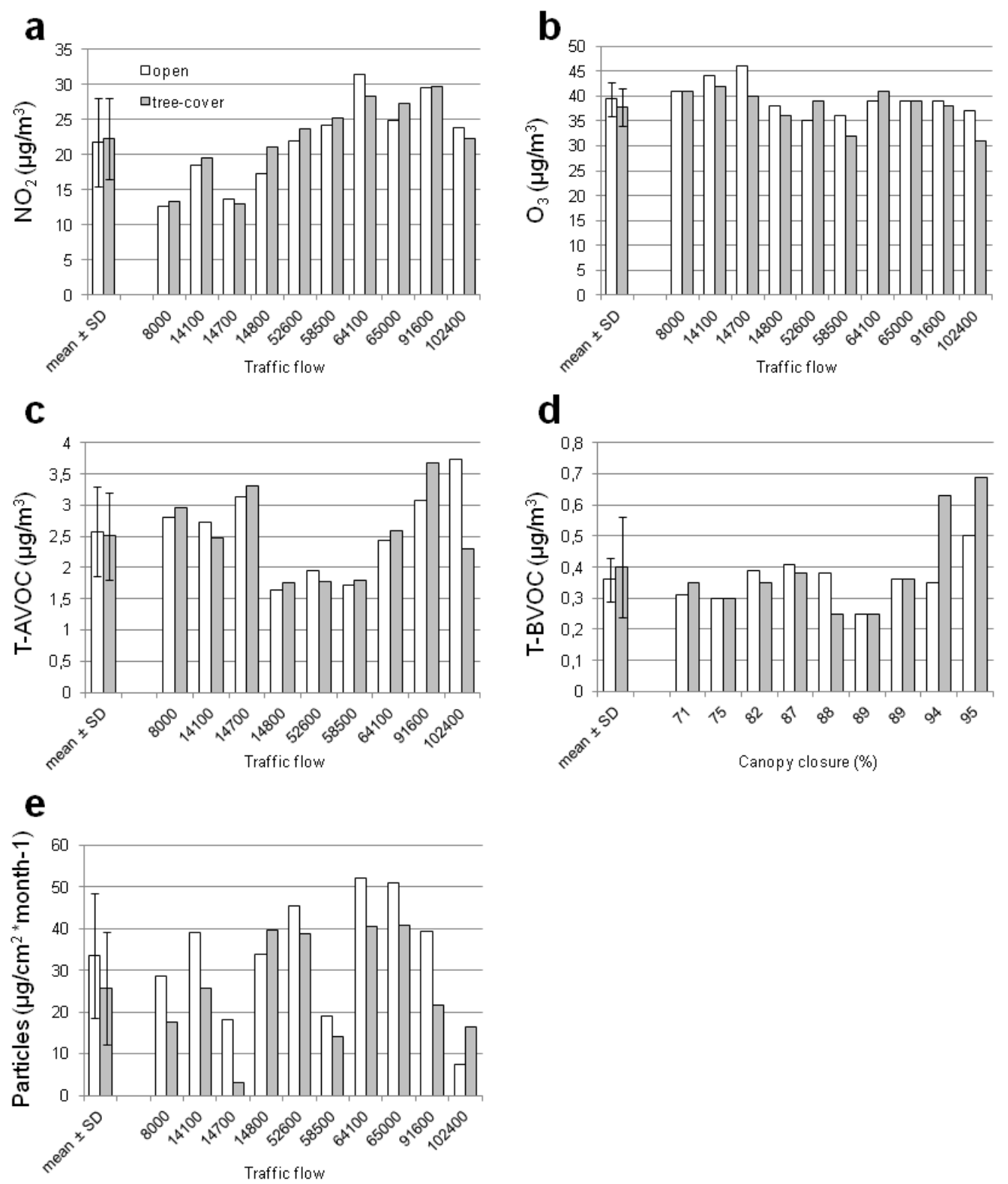
Fig. 3. Concentrations of (a) $\mathrm{NO}_{2}$, (b) $\mathrm{O}_{3}$, (c) total AVOCs, (d) total BVOCs and (e) levels of particles (mass of airborne particles deposited on the sampler) in open (white bars) and treecovered (grey bars) areas. The first pair of bars in each panel refers to mean \pm SD $(n=10$, except for total AVOCs and total BVOCs where $n=9$ due to a lost VOC sample in one tree-covered study area) pollution levels of all 10 study sites. The rest of the bar pairs describe each study site separately. The sites are presented in relation to increasing traffic flow (number of motor vehicles day ${ }^{-1}$ ), except for T-BVOCs (panel d), where data are presented in relation to \% canopy closure. 